„Nasza Przeszłość” t. 136: 2021

DOI: $10.52204 / \mathrm{np} .2021 .136 .169-180$

Rev. PETER BORZA, Pavol Jozef Šafárik University in Košice Faculty of Arts

ORCID: 0000-0002-1447-3672

peter.borza@upjs.sk

\title{
COOPERATION OF GREEK CATHOLICS FROM INTERWAR POLAND AND CZECHOSLOVAKIA ON THE EXAMPLE OF THE CONGREGATION OF THE SISTERS OF THE SERVANTS OF THE IMMACULATE VIRGIN MARY
}

\begin{abstract}
In the interwar period, new state units such as Czechoslovakia and Poland were formed in Central Europe. Churches and their institutions focused on education, training or social care also played an important role in shaping the loyalty and national awareness of the citizens of the new states. Among such institutions was the Congregation of the Sisters of the Servants of the Immaculate Conception (abbreviated as the Maid), which was established in the territory of interwar Poland. In a short time, it was a great success and achieved a response among Greek Catholics in Czechoslovakia. In 1928, at the invitation of the Bishop of Prešov, Pavel Gojdič, four sisters came to Prešov in cooperation with the local Greek Catholic Church to establish a monastery and devote themselves to education, training and social services. The arrival was accompanied by complications with visas from Czechoslovakia. The reason was the Ukrainian environment where the maids came from. In Poland, it was characterized by a high degree of nationalism and the idea of so-called Greater Ukraine, which also included part of Czechoslovakia. Visa permits were issued only after a clear argument from the bishop of Prešov about the apolitical nature of the service of nuns in eastern Slovakia. For his purpose, Bishop Gojdič received the support of the Pope and the Czechoslovak President. The result was the successfully developing ministry of maid sisters, which was stopped only by the onset of the communist regime. The cooperation of Greek Catholics from Poland and Czechoslovakia in the interwar period enabled the nuns to lead the apostolate in the social field of the church, and despite the forced break caused by the communist regime, they continue to do so throughout Slovakia.
\end{abstract}

KEYWORDS: Poland, Czecho-Slovakia, Greek Catholic Church, maid, the Ukrainian question.

\section{WSPÓŁPRACA GREKOKATOLIKÓW Z MIĘDZYWOJENNEJ POLSKI I CZECHOSŁOWACJI NA PRZYKŁADZIE ZGROMADZENIA SIÓSTR SŁUŻEBNIC NIEPOKALANEJ MARII PANNY}

STRESZCZENIE: W okresie międzywojennym w Europie Środkowej powstały nowe jednostki państwowe, takie jak Czechosłowacja i Polska. Ważną rolę w kształtowaniu lojalności i świadomości narodowej obywateli nowych państw odegrały także Kościoły 
i ich instytucje skoncentrowane na edukacji, szkoleniu czy opiece społecznej. Wśród takich instytucji znalazło się Zgromadzenie Sióstr Służebnic Niepokalanego Poczęcia (w skrócie Siostry Służebnice), które powstało na terenie międzywojennej Polski. W krótkim czasie odniosły one wielki sukces i spotkały się z odzewem wśród grekokatolików w Czechosłowacji. W 1928 r. na zaproszenie biskupa preszowskiego Pavla Gojdiča cztery siostry przybyły do Preszowa we współpracy z miejscowym kościołem greckokatolickim, aby założyć klasztor i poświęcić się edukacji, szkoleniom i służbom socjalnym. Przybyciu towarzyszyły komplikacje z wizami czechosłowackimi. Powodem było ukraińskie pochodzenie Sióstr Służebnic. W Polsce środowisko ukraińskie charakteryzowało się wysokim stopniem nacjonalizmu i ideą tzw. Wielkiej Ukrainy, która obejmowała również terenów ówczesnej Czechosłowacji. Zezwolenia na wizy wydano dopiero po wyraźnym oświadczeniu biskupa preszowskiego o apolitycznym charakterze służby Sióstr we wschodniej Słowacji. Biskup Gojdič otrzymał w tym celu wsparcie papieża i prezydenta Czechosłowacji. Efektem była pomyślnie rozwijająca się służba Sióstr Służebnic, którą przerwał dopiero nadejście reżimu komunistycznego. Współpraca grekokatolików z Polski i Czechosłowacji w okresie międzywojennym umożliwiła Siostrom Służebnicom prowadzenie apostolatu na polu społecznym Kościoła i pomimo przymusowej przerwy spowodowanej przez reżim komunistyczny, nadal to czynią na terenie całej Słowacji.

SŁOWA KLUCZOWE: Polska, Czechosłowacja, Kościół greckokatolicki, Siostry Służebnice, kwestia ukraińska.

Ttumaczenie Peter Borza

The interwar period in Central Europe was characterized by the strengthening of the identities and functions of the new states that emerged in the area of defunct monarchies such as the German Empire and the Austro-Hungarian monarchy. Changes were taking place in the environment of Poland and Czechoslovakia, creating new political and social conditions. Important factors were the national identity and loyalty of the population to the new state departments. The governments of both states sought to build prosperous and secure states for their citizens firmly entrenched in international structures.

Churches and their institutions focused on education, training or social care also played an important role in shaping the loyalty and national awareness of citizens. Among such institutions we also include the Congregation of the Sisters of the Servants of the Immaculate Virgin Mary (for short, the Sisters of the Servants or SSNPM). It was established as the first active order of the Byzantine ceremony for the needs of Ukrainian Greek Catholics in Galicia. It was founded in 1892 by the Basilian priest Jeremiáš Lomnický OSBM and the parish priest 
of the village Žužel ${ }^{1}$ Cyril Selecký together with his sister Jozafata Hordaševská ${ }^{2}$. The order responded to the needs of the Greek Catholic Church in Galicia and focused on the education of children and youth, health and social service, and care for God's temples. Within a few years, it grew and expanded not only in Galicia but also abroad - Canada, the USA and Brazil. In the interwar period, she was the most popular Greek Catholic female order in Poland and had 81 houses (monasteries) with 463 sisters. She worked among about five million Greek Catholics in the Galician-Lviv metropolis, the eparchy of Przemyśl and the Apostolic Administration for Lemkov ${ }^{3}$.

The positive contribution of the nuns also received a response among Greek Catholics in Czechoslovakia. They were organized in two dioceses based in Uzhhorod and Prešov. In the interwar period, 585,041 Greek Catholics lived out of the total population of 14,729,536 throughout Czechoslovakia ${ }^{4}$.

\footnotetext{
1 Žužel'any in the Sokal' region of Ukraine.

2 Michaela Jozafata Hordaševska was born on November 20, 1869 in Lviv. During missions for Lviv youth at the age of nineteen, she learned about. Jeremiah Lomnicky, OSBM, who became its spiritual leader. Under his leadership, on June 24, 1889, she took a private vow of purity in Lviv for one year and later renewed it for three years. At the instigation of Lomnický, he is considering religious life in a new congregation. For a time he lived in the monastery of the Polish Sisters Feliciánok in Žovka, but on August 24, 1892 he was solemnly received in the Church of St. Onufria in Lviv hand-designed and sewn monk's robe. He gets a new name - Jehoshaphat. After getting dressed, she moved to a house in Žužel, which he prepared for. Cyril Selecký, one of the founders of the Congregation of the Sisters of the Servant of the Immaculate Virgin Mary. On November 20,1892 , she publicly made her first religious vows of purity, poverty, and obedience for three years. A year later, she opened her first kindergarten. She took her eternal vows on May 11, 1909. She became ill in 1914, and five years later, after severe and painful tuberculosis, she died on the feast of the Annunciation, according to the Julian calendar used at the time, on April 7, 1919. Pope John Paul II declared her blessed. June 27, 2001 in Lviv. We celebrate her holiday on the calendar on November 20. Por. https://grkatba.sk/ sto-rokov-od-narodenia-bl-jozafaty-hordasevskej/ [access: 1.06.2021].

3 Por. I. H ałagi da, Międzi Moskwa, Warszawa i Watykanem. Dzieje Kościota greckokatolickiego $w$ Polsce w latach 1944-1970, Warszawa 2013, s. 45-46; B. K u m o r, Historia kościoła VIII., Lublin 2001, s. 418.

${ }^{4}$ Por. Sčítání lidu v republice Československé ze dne 1. prosince 1930. Díl I. Praha, 1934, s. $100-102$.
} 
In 1926, the newly appointed Bishop of Prešov, Pavel Gojdič, visited the $\mathrm{OSBM}^{5}$ Galicia, where he took refuge in the Krechiv Monastery near Lviv before making eternal vows. During his stay he visited the Basilian monasteries in Lviv, Dobromyla, Krystynopili and Przemyśl. There were also nuns ministers in kindergartens, a seminary, or a school. He became acquainted with their work for the local church and appreciated their contribution ${ }^{6}$.

The social situation in the 1920s was difficult in Galicia and also in the east of the Czechoslovak Republic. Poverty and lack of job opportunities have led to the departure of villages to large cities or abroad. The success of the maid sisters was so impressed by Pavel Gojdič that after the episcopal ordination and enthronement in Prešov, in addition to the spiritual area, he also focused on the social dimension of the life of the believers of the Prešov eparchy. He considered orphans and the elderly to be most at risk. Therefore, soon after he took office, he started working on the project of an eparchial orphanage and a home for the elderly in Prešov. In carrying out his plan, he counted on the participation of the nuns. At the same time, he needed them to strengthen educational activities such as the Marian company and the Society of St. Anny designed for maids. Thanks to him, the young girls had proper employment contracts and rights guaranteed by the Association of St. Anny ${ }^{7}$.

Bishop Pavel addressed the General Superior of the Sisters of the Servants, Veronika Gargil, who in mid-February 1928 agreed to send 4 sisters at the invitation of Bishop Pavel. The following administrative

\footnotetext{
${ }^{5}$ He was born on July 17, 1888 in the family of a Greek Catholic priest in the village of Ruské Pekl'any near Prešov. He studied in Bardejov, Prešov and completed his theological studies in Budapest. He received the sacrament of the priesthood on August 27, 1911 in Prešov. He worked in Sabinov and Prešov. In 1922 he entered the monastery of St. Basil the Great in Mukachevo. He received episcopal ordination on March 25, 1927 in the Basilica of St. Clement in Rome. In January 1951, he was sentenced to life imprisonment in monster trial together with Bishops Vojtaššák and Buzalka. He died as a result of the communist imprisonment in Leopoldov on July 17, 1960. He was blessed by Pope St. John Paul II. in 2001 in Rome. In 2007, he was awarded the title of Righteous Among the Nations by the State of Israel in memoriam. Por. M. H r o m n í k, Blahoslavený Pavol Peter Gojdič, OSBM, Prešov 2007, s. 54. ${ }^{6}$ Por. M. P o t a š, Dar lásky. Spomienky na biskupa Pavla Gojdiča OSBM, Prešov 2001, s. $49-58$.

${ }^{7}$ Por. Team of authors, J. E. Pavel Gojdič ČSVV. K jeho dvadcat'ročnému jubileju so dňa jep. Posvjaščenija, Prešov 1947, s. 76-82.
} 
process of obtaining travel documents and visas for a stay in Czechoslovakia revealed the complexities of policies in both countries. Both Poland and Czechoslovakia were multinational states. In Poland, the largest minority was Ukrainians, with about 5 million citizens. At the end of the First World War on November 1, 1918, they sought independence by declaring an independent West Ukrainian People's Republic. This led to a conflict with the Polish army, and after Poland's victory, some Ukrainians felt occupied, but a significant part gradually integrated and developed under the conditions of the new state. A radical group represented by the Ukrainian Military Organization (UVO) and later the Organization of Ukrainian Nationalists (OUN) led a campaign for the idea of Greater Ukraine in the interwar period. It used various terrorist acts in the form of sabotage, bombings and assassinations aimed at state property or government officials. Radical groups also found their supporters in Czechoslovakia. It was mainly the territory of Subcarpathian Russia and marginally also in eastern Slovakia. The Polish „Ukrainian problem” was in a way also a problem in the Czechoslovak Republic $^{8}$. Especially in the late 1930s, the OUN established itself among young people in Subcarpathian Russia. Its members wanted to push for the creation of the so-called Greater Ukraine, of which Subcarpathian Rus was supposed to be a part. The founding meeting of the Karpatská Sič National Defense Organization took place in Khust on November 9, 1938. The commander was Dmitro Klimpush from Jasin in Subcarpathian Russia, but the main organizers were officers of the military organization OUN from Galicia, Poland ${ }^{9}$. Since 1920, Ukrainian ideas in the Czechoslovak Republic have found breeding ground in the activities of the Prosvita association under the clear influence of Galicia ${ }^{10}$.

The lengthy issuance of visas from February to September 1928 for the servant sisters Eudoki Vološinová, Teónia Blizňuková, Mitrofana Michalecká and Kriskentia Hodovanská pointed to the fear of

\footnotetext{
${ }^{8}$ Por. P. M a g o c s i, Chrbtom k horám. Dejiny Karaptskej Rusi a karpatskych Rusinov, Prešov 2016, s. 290-291.

${ }^{9}$ Por. J. R y c h 1 í k, M. R y c h lík o vá, Podkarpatká Rus v dějinách Československa 1918-1946, Praha 2016, s. 74-81.

10 The Prosvita Association united mainly Ukrainian intelligence from the environment of the Greek Catholic and Orthodox Church in the Czechoslovak Republic. Por. P. B o r z a, Gréckokatolicka cirkev na okupovaných územiach Československa 1938-1945, Košice 2019, s. 23-26.
} 
representatives of Czechoslovak state authorities about strengthening Ukrainian ideological influences in the east of the republic. At the same time, they were aware of the contribution of the orphanage and other activities in the field of education among Greek Catholics. At the request of Bishop Gojdič, the police directorate issued a residence permit for the maids, but the Ministry of the Interior examined the nuns and delayed the statement for the Ministry of Foreign Affairs. To convince the state authorities, Bishop Gojdič asked the help of several influential people to explain the apolitical nature and importance of the service of the invited sisters to the Greek Catholic Church. He wrote to a member of the National Assembly in Prague, Martin Mičur: ,There are many poor girls among our people who would like to enter the monastery. In order to comply with their request, I founded a monastery in Prešov - an orphanage, for the purpose of which I have already taken all the steps. The police headquarters in Prešov had no objections to the arrival of 4 nuns - the sisters of a maid from Lwow (Poland), who would raise girls from our nation, consecrated to this noble office. But now that everything has been prepared, the appointed nuns - maids - from Poland cannot obtain a visa from the Czech consul, despite the fact that the consulate has twice telegraphed the Ministry in Prague, and has not received an answer. For this reason, please, Your Minister, please do it in the Ministry for the Lviv Czech Consul to give the appointed nuns - nurse maids - the requested visa, all the more so because these nuns can never harm our state, only always the state and the church. useful work can be demonstrated"11. At the end of August 1928, with a similar content, but with an emphasis on apoliticalism, a letter was sent to the trade union chief of the Ministry of the Interior, Ladislav Černocký: They can no longer interfere in politics because of their profession. So please, let your serious person act on the whole matter, so that the four sisters give them the necessary visas from the Lviv consulate of Czechoslovakia. Republic as soon as possible"12. At the beginning of September, the results of intensive communication appeared, and after the visas were granted, the nuns could arrive in Prešov. Their further activity confirmed the intention of Bishop Gojdič.

\footnotetext{
11 F. K. M i nč i č o vá, Sestry služobnice v Prešove. Prichod a pôsobenie sestier služobnic v Prešove v rokoch 1928-1947, Prešov 2021, s. 21-22.

12 Ibid, s. 23.
} 
On September 10, 1928, the superiors of sr. Eudokima, deputy sr. Teónia, teacher sr. Mitrofana et al. Crisis ready to serve the sick. They took over the administration of the kitchen and economy in the seminary. Even before their arrival, the bishop addressed the clergy of the eparchy with a vision of founding a monastery in Prešov. He used the contributions to buy the land and took care of the preparation of project documentation $^{13}$. For the orphanage project, he received not only the support of the clergy and believers of the eparchy, but also of Pope Pius XI, sister churches abroad and especially the President of the Czechoslovak Republic Tomáš Garrique Masaryk as well as state institutions. The President also entered the project documentation and proposed to proceed in a new architectural style - functionalism characteristic of the Czechoslovak Republic. The state support was also comprehensive because the orphanage building was built next to the new hospital complex. Upon completion, the orphanage was to serve primarily orphans and the elderly, who would be close to medical care in the hospital ${ }^{14}$. The sisters, meanwhile, lived in a seminary and after a year moved to a nearby bishop's residence. They devoted themselves to the education of children and girls' youth, the sick and took care of the entrusted chapels and the sacristy of the cathedral, they also sewed liturgical robes and objects.

The construction of the orphanage began on September 11, 1932, when Bishop Gojdič performed a ceremonial dedication of the foundation stone of the orphanage and the future chapel on Sunday afternoon. In addition to Bishop Gojdič and his entourage, the school youth, members of the Association of St. Anny and the Society of the Mother of Constant Relief, Basilians, servant sisters, clergy, members of the Prešov chapter and a large number of believers. Construction continued relatively quickly, and on April 29, 1934, Bishop Gojdič and Bishop Dionýz Nyáradi consecrated one wing of the new building. Although it was not fully completed until a year later, on May 1, 1934, the orphanage began operations; on this day the maid's sisters entered the orphanage. The whole work, including the land, cost 1,052,000 Czechoslovak crowns (CZK). Pope Pius XI also contributed to it. and Czechoslovak

\footnotetext{
${ }^{13}$ Por. Ibid, s. 29-40.

14 Por. P. K o v a l', Z histórie prešovského zdravotníctva - Okresná verejná nemocnica, T. G. M a s a r y k a, In J. K u š n í r, Prešov v priestore a čase, Prešov 2017, s. 190-199.
} 
President Tomáš Garrique Masaryk, Regional Office, believers from the United States of America and the Prešov Diocese. Other benefactors also contributed to the construction, but nevertheless the entire amount was offset by a loan from the Central Social Insurance Agency in Prague in the amount of CZK 200,000 ${ }^{15}$.

The modern functionalist building served its purpose until the abolition of the Greek Catholic Church by the communist regime in 1950. Today it houses a Greek Catholic priestly seminary, but near the entrance to the chapel there is still a memorial plaque commemorating the benefactors, thanks to which the orphanage could be built.

The Greek Catholic orphanage with the convent of the nuns was a religious and cultural center for the inhabitants of Prešov, but mainly for the school youth. It often featured orphans or children with their program from the kindergarten run by the nuns. In the first year of activity, 11 children found their home in the orphanage, later their number increased to 50 orphan girls. Depending on the age, the length of stay in it varied. The orphans left the orphanage only after the overall livelihood, e.g. after the end of a teaching academy, grammar school, family school, tailoring course or at least after the completion of four classes of a burgher school. Girls who studied at a grammar school or a teaching academy also found a temporary home in an orphanage. The orphanage residents' daily program began at six in the morning and was interspersed with prayer, study, or play in kindergarten and school. The children also had plenty of free time and went to bed at half past eight in the evening ${ }^{16}$.

The orphanage was funded from several sources. In the first place, it was the income from the property of the orphanage, maintenance allowances provided by the municipalities or living relatives of orphans or the elderly, as the orphanage also served as an old-fashioned house. Then there were monetary and in-kind alms and various fixed or variable subsidies. In 1937, the orphanage's income in the amount of CZK 42,150 consisted of funds provided by the Ministry of Social Welfare, the Regional Office, Bishop Gojdič, individual district offices, the Central Social Insurance Agency, voluntary donations, parishes, as well as

\footnotetext{
${ }^{15}$ Archive SSNPM-PSK, fond C3b, sign. 6. Application for a subsidy.

16 P. B o r z a, Gréckokatolícka cirkev a Židia na Slovensku v rokoch 1939-1945, Prešov 2017.
} 
funds obtained for manual work. However, the expenses amounted to CZK 63,015, which means that the orphanage was at a loss of CZK 20,865 in 1937. Bishop Gojdic tried to make up for this loss from the diocese. A regular contributor was the papal prelate of the Prešov canon Dr. Mikuláš Russnák, who bought children clothes, shoes and various necessary things. An important source to cover operating costs were collections for the needs of the orphanage carried out with the consent of state authorities and held by nuns who traveled in pairs around Slovakia ${ }^{17}$.

In 1943, a branch of an orphanage began to be built in Lutina near Sabinov, so that children could go on recreation in nature, the beautiful environment of the Marian pilgrimage site, where the bishop of Prešov often came. Far from the hustle and bustle of the city, they had to gain strength and strengthen their health ${ }^{18}$. The successful project of the Greek Catholic orphanage stopped and destroyed the communist regime in 1950. Not forever. After the restoration of freedom in 1989, the female nuns managed to build on the previous period and resume their activities in Slovakia.

The arrival of nuns workers from interwar Poland to Czechoslovakia in 1928 brought a new impetus to the Greek Catholic Church in the field of education. The bishop of Prešov created appropriate conditions for the nuns, and they fully focused on the works that were their own. Service in a priestly seminary, running an orphanage, founding kindergartens and leading girls' youth in Marian groups or the Association of St. Anny was a positive contribution from the sisters of the Church and society. With their work and life, they confirmed the intention of Bishop Gojdič and dispelled any suspicions of state authorities due to their nationality or the Ukrainian environment from which they came. The first four sisters created space for the development of a congregation that was growing in number of sisters from the local church. Eudokima's sister

\footnotetext{
${ }^{17}$ Archive SSNPM-PSK, fond C3b, sign. 13. Accounting report of the Greek Catholic orphanage for the year 1937.

${ }_{18}$ Archive SSNPM-PSK, fond C3a, sign. 33. Budget for the construction of a Greek Catholic orphanage, branch of Lutina.
} 
Olena Vološinová went to Rome in 1932, where she worked in the Pontifical College of St. Jehoshaphat until his death on May 15, 1975. The other three sisters remained in Czechoslovakia and bore the burden of persecution by the communist regime. After arriving in Prešov, Sister Teónia Agafia Blizňuková worked as a cook in a priestly seminary, a bishop's residence and finally in an orphanage. In 1937 she left for the newly opened mission of the sisters in Michalovce. She held the position of superior in the convent, where the kindergarten and dormitory for girls were located. After the liquidation of the monasteries in 1950, she was deported to the centralization monastery in Kostolná near Trenčín, later to Modra, Jasov and Sládečkoviec, where she died on June 15, 1980. Mitrofan's sister Júlia Michalecka educated girls in Prešov, taught religion and took care of orphans in an orphanage. During communism, she worked at the hospital in Uherský Hradiště and the retirement home in Kolešovice until her death on January 9, 1975. Kriskentia's sister Ol'ga Hodovanska worked in a seminary, a bishop's residence and was in charge of the sacristy in an orphanage. After the founding of the monastery in Trebišov, she became his superior. In 1949 she was deported to the centralized monastery in Kostolná near Trenčín, from there to Modra, Jasov and in 1955 to Sládečkovce, where she died on November 6, $1975^{19}$.

The Congregation of the Sisters of the Servants of the Immaculate Conception is still developing today as the fruit of the work of sisters from interwar Poland. In Slovakia, it operates in the cities of Prešov, Košice, Michalovce, Stará L'ubovňa, Humenné, Poprad, Trenčín and the municipality of Lutina. It has 12 houses - monasteries and 54 sisters. Operated by the hospice Dom sv. Kozma and Damián in Prešov and kindergartens bl. Jozafáty v L'utine a bl. Tarzic in Trencin ${ }^{20}$.

${ }^{19}$ F. K. M i n č i č o v á, Sestry služobnice..., s. 18.

${ }^{20} \mathrm{http}: / / w w w . s l u z o b n i c e . s k /[$ access:: 1.06.2021]. 


\section{BIBLIOGRAPHY}

\section{Archival Sources}

\section{Archive of the Congregation of the Sisters of the Servants of the Immaculate Virgin Mary in Presov (SSNPM-PSK)}

Fond: $\mathrm{C} 3 \mathrm{a}$

- sign. 33, Budget for the construction of a Greek Catholic orphanage, branch of Lutina.

Fond: $\mathrm{C} 3 \mathrm{~b}$

- sign. 6, Application for a subsidy.

- sign. 13, Accounting report of the Greek Catholic Orphanage for the year 1937.

\section{Literature}

Borza, P., Gréckokatolícka cirkev a Židia na Slovensku v rokoch 1939-1945, Prešov 2017.

Borza, P., Gréckokatolicka cirkev na okupovaných územiach Československa 1938-1945, Košice 2019.

Hałagida, I., Międzi Moskwa, Warszawa i Watykanem. Dzieje Kościoła greckokatolickiego w Polsce w latach 1944-1970, Warszawa 2013.

Hromník, M., Blahoslavený Pavol Peter Gojdič, OSBM, Prešov 2007. http://www.sluzobnice.sk/ [access: 1.06.2021].

https://grkatba.sk/sto-rokov-od-narodenia-bl-jozafaty-hordasevskej/ [access: 1.06.2021].

Koval', P., Z histórie prešovského zdravotníctva - Okresná verejná nemocnica

T. G. Masaryka, In J. Kušnír, Prešov v priestore a čase, Prešov 2017.

Kumor, B., Historia kościoła VIII., Lublin 2001.

Magocsi, P., Chrbtom k horám. Dejiny Karaptskej Rusi a karpatskych Rusínov, Prešov 2016.

Minčičová, F. K., Sestry služobnice v Prešove. Príchod a pôsobenie sestier služobníc v Prešove v rokoch 1928-1947, Prešov 2021.

Potaš, M., Dar lásky. Spomienky na biskupa Pavla Gojdiča OSBM, Prešov 2001.

Rychlík, J., Rychlíková, M., Podkarpatká Rus v dějinách Československa 1918-1946, Praha 2016.

Sčitání lidu v republice Československé ze dne 1. prosince 1930. Díl I. Praha, 1934. Team of authors, J. E. Pavel Gojdič ČSVV. K jeho dvadcat'ročnému jubileju so ďna jep. Posvjaščenija, Prešov 1947. 
Rev. PETER BORZA - doc. ThDr., Ph.D., he is a historian, a Greek Catholic priest of the Prešov archieparchy. He works in the Department of History at the Faculty of Philosophy of the University of Pavol Jozef Šafárik in Košice. In his research, he focuses on the history of the Catholic Church in the 20th century, and especially the Greek Catholic church in 1939-1945. He published several monographs and articles on the subject. He presented the results of his research in many forums in Europe, the USA and Israel. $\mathrm{He}$ collaborates with the Institute of Nation Remembrance and the Holocaust Museum in Seredi. 